

\section{Obsah Content}

EDITORIAL EDITORIÁL

2 Henrieta Moravčíková, Peter Szalay

(UN)PLANNED CITY

(NE)PLÁNOVANÉ MESTO

VEDECKÉ ŠTÚDIE SCIENTIFIC STUDIES

6 Lýdia Grešáková, Zuzana Tabačková, Zuzana Révészová MAPPING WITH CARE AS AN OUTLINE FOR POSTNEOLIBERAL ARCHITECTURE METHODOLOGIES TOOLS OF THE "NEVER-NEVER SCHOOL" MAPOVANIE SO STAROSTLIVOSŤOU AKO PODKLAD PRE POST NEOLIBERÁLNE ARCHITEKTONICKÉ METODOLÓGIE - NÁSTROJE „NEVER-NEVER SCHOOL”

20 Peter J. Larkham

BRITISH URBAN RECONSTRUCTION AFTER THE SECOND WORLD WAR: THE RISE OF PLANNING AND THE ISSUE OF "NON-PLANNING"

BRITSKÁ OBNOVA MIEST PO DRUHEJ SVETOVEJ VOJNE: VZOSTUP PLÁNOVANIA A OTÁZKA“NEPLÁNOVANIA"

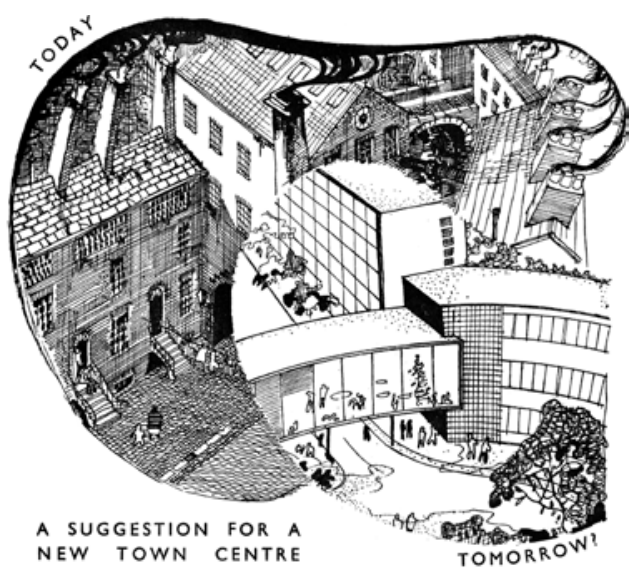

32 Matěj Spurný

URBAN EXPERTS IN THE BUILDING

OF POST-STALINIST BRATISLAVA

URBÁNNII EXPERTI A BUDOVÁNÍ BRATISLAVY

$\checkmark$ ÉŘE POSTSTALINISMU

44 Anna Kornélia Losonczy, Regina Balla, Hlib Antypenko, Melinda Benkö

RE-SHAPING BUDAPEST: LARGE HOUSING ESTATES

AND THEIR (UN)PLANNED CENTERS

PRETVORIŤ BUDAPEŠŤ: VEL'KÉ SÍDLISKÁ

A ICH (NE)PLÁNOVANÉ CENTRÁ

56 Karel Maier

PLANNING OF BOHEMIAN REGIONAL CENTRES IN THE PERIOD OF THEIR INDUSTRIALISATION AND MODERNISATION: PLZEŇ AND HRADEC KRÁLOVÉ $1860-1938$

PLÁNOVÁNÍ ČESKÝCH REGIONÁLNÍCH CENTER

V OBDOBÍ INDUSTRIALIZACE A MODERNIZACE:

PLZEŇ A HRADEC KRÁLOVÉ 1860 - 1938
70 Adriana Priatková, Ján Sekan Máté Tamáska THE URBAN PLANNING OF KOŠICE AND THE DEVELOPMENT OF A 2OTH CENTURY AVENUE MESTSKÉ PLÁNOVANIE V KOŠICIACHA VÝVOJ MESTSKEJ TRIEDY 2O. STOROČIA

\section{$89 \quad$ Klára Brůhová}

THE PARLIAMENT FOR PRAGUE - PROPOSALS COMPETITIONS AND DEBATES ON ITS LOCATION AND ARCHITECTURE

PARLAMENT PRO PRAHU - NÁVRHY, SOUTĚŽE A DEBATY NAD UMÍSTĚNIIM A ARCHITEKTONICKOU FORMOU KOMPLEXU

106 Lina Degtyaryova, Oleg Olashyn

URBAN PLANNING AND CONSTRUCTION OF THE INTERWAR CITY OF UZHHOROD: MISSION INTERRUPTED PLÁNOVANIE A VÝSTAVBA MESTA UŽHOROD VMEDZIVOJNOVOM OBDOBÍ: PRERUŠENÁ MISIA

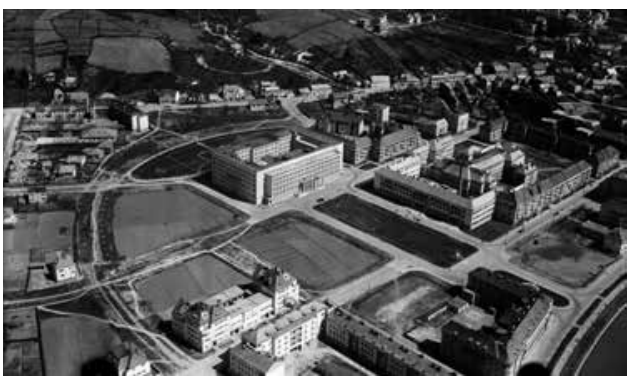

116 Peter Stec

CREATIVE TRANSFORMATIONS: THE CAMPUS PARADIGM KREATIVNE TRANSFORMÁCIE: PARADIGMA KAMPUSU

134 Gonçalo M. Furtado C. L.

THE LEGACY OF THE IGNASI SOLÀ-MORALES AND THE CONTEMPORARY URBAN DEBATE ODKAZ IGNASIHO SOLÀ-MORALESA A SUCASNA DEBATA O MESTE

RECENZIE REWIEVS

145 Zoltán Bereczki PATTERN RECOGNITION ROZPOZNÁVANIE VZOROV

148 Peter Szalay

MOC EXPERTOV: KONTINUITY ČI RUPTÚRY PRED A PO ROKU 1989

THE POWER OF EXPERTS: CONTINUITIES OR RUPTURES BEFORE AND AFTER 1989

150 Katarína Haberlandová

SANDALOVA MIMORIADNA HĹBKA OSTROSTI

SANDALO'S EXCEPTIONAL DEPTH OF SHARPNESS 


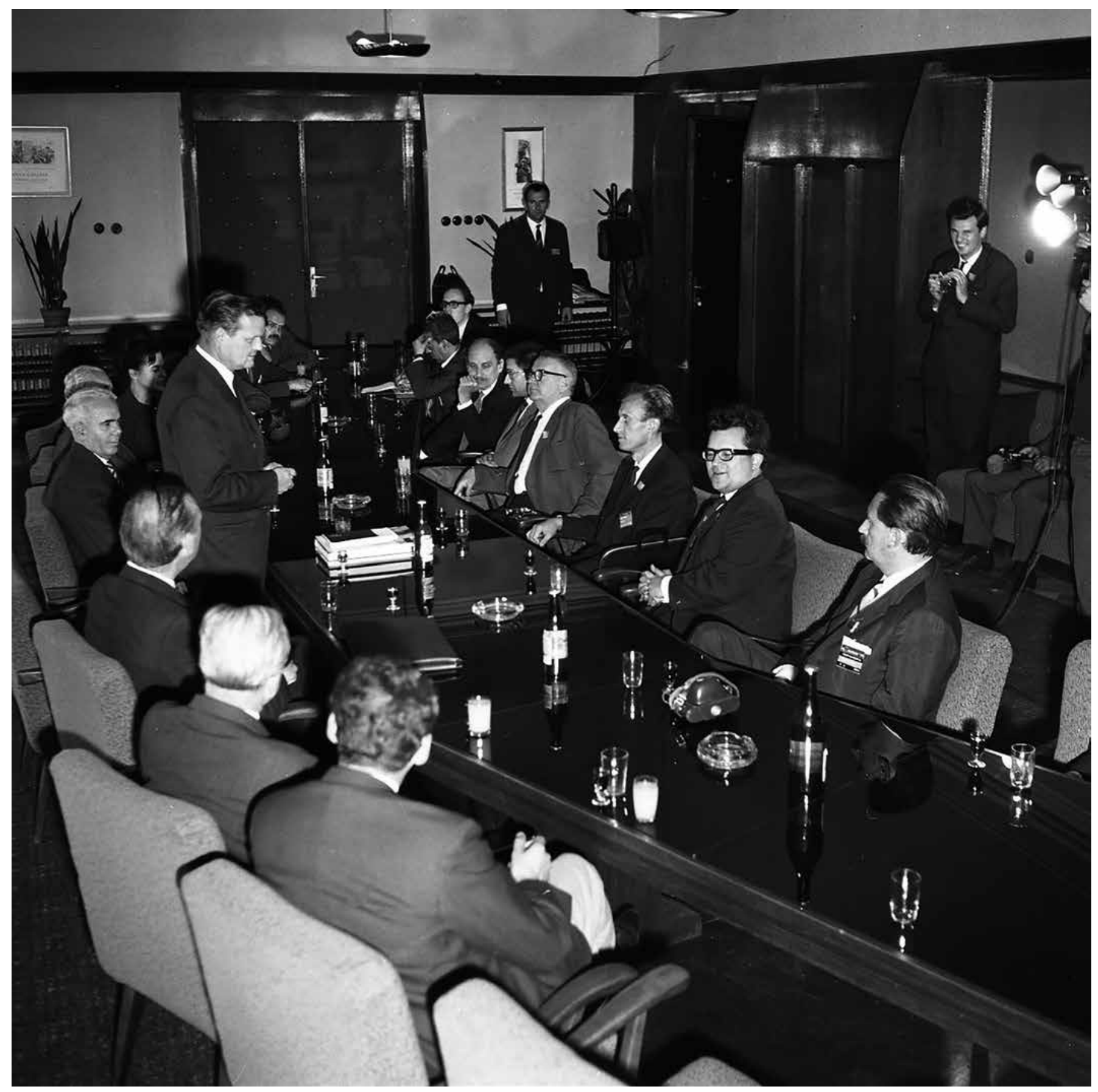

CHAIRMAN OF THE BRATISLAVA

MUNICIPAL NATIONAL

COMMITTEE, MILAN HLADKÝ

(STANDING) WELCOMING THE

DELEGATION OF PERMANENT

TOWN PLANNING COMMISSION OF

THE UIA, JULY 10. 1967.

PREDSEDA MSNV VBRATISLAVE MILAN HLADKÝ (STOJACI) VÍTA

DELEGÁCIU ČLENOV STÁLEJ

URBANISTICKEJ KOMISIE UIA,

10.7.1967.

Source Zdroj: TASR 


\section{Urban Experts in the Building of Post-Stalinist Bratislava \\ Urbánní experti a budování Bratislavy \\ vére poststalinismu}

Matěj Spurný

Bratislava patřila po celou éru státního socialismu mezi nejrychleji rostoucí československá města. Po válce a nuceném vysídlení německého obyvatelstva ji obývalo jen o málo více než 100000 lidí, o pouhé čtyři desítky let později, na sklonku státního socialismu, se jednalo již o téměř půlmilionovou metropoli. Tento vývoj akceleroval na přelomu šedesátých a sedmdesátých let, kdy se stala hlavním městem Slovenské socialistické republiky a vedle funkce hospodárského centra rychle se urbanizujícího Slovenska přijala i novou politickou, kulturní a symbolickou roli. Již od padesátých let znamenal př́liv lidí z celého Slovenska pro budovatele a správce města nejednoduchou výzvu. Učinit z města regionálního významu, zasazeného mezi Dunaj a úbočí Malých Karpat, navíc nedaleko hranic s Rakouskem a Madarskem, rozvíjející se metropoli si žádalo intenzivní spolupráci politiků a vysoce postavených úředníků s kvalifikovanými, zkušenými i inovativními experty v oboru městského plánování, dopravního inženýrství a architektury. Tato poptávka urbánním expertům postupně otevřela dveře nejen ke značné odborné autoritě a k posilování pozice vlastních svazů či institucí, ale zároveň $\mathrm{i} \mathrm{k}$ důležitým pozicím ve správě města včetně nejvyšších politických funkcí.

Předkládaná studie nesleduje primárně podobu a chronologii výstavby (to je již s úspěchem popsáno jinde), ale zaměřuje se na její intelektuální kořeny, myšlenkové kontinuity, na organizaci budování města a na vliv či moc jednotlivých skupin aktérů v době, kdy se rozhodovalo o rámcových podmínkách a charakteru výstavby města $v$ posledních dvou dekádách státně socialistického Československa (a tak do velké míry i o jeho současné podobě). Studii je možné číst i jako snahu přezkoumat, nakolik je v éře šedesátých a zčásti i sedmdesátých let smysluplné předpokládat dichotomii mezi politiky (reprezentujícími v systému státního socialismu oficiální ideologii) a experty v jejich službách. Nebyli to právě experti - technokraté, kdo $\mathrm{v}$ ére poválečné modernity tř́mal $\mathrm{v}$ rukou skutečnou moc nad organizací prostoru, estetikou budov či podobou bydlení, tedy nad záležitostmi zásadně strukturujícími, ba určujícími každodennost městského člověka?

Dvě dekády od poloviny padesátých do poloviny sedmdesátých let jsou poměrně neklidným časem s mnoha politickými mezníky, ale i časem značné společenské mobility a zásadní proměny infrastruktury. Pokud jde o roli expertů v procesu budování města, je tak možné vedle kontinuit sledovat rovněž podstatné proměny. Především jsou to rozdíly ve strategiích, rolích a mocenských nástrojích mezi dvěma generacemi urbánních expertů - lidí narozených (jako Vladimír Karfík či Emil Belluš) kolem roku 1900 a architektů či projektantů, kteři přišli na svět zhruba o čtvrt století později (jako byli Milan Hladký, Štefan Svetko nebo Dušan Kedro). Zatímco př́slušníci první zmiňované generace přesvědčovali o svých postojích především prostřednictvím svých vysokoškolských ústavů a odborných časopisů, jejich mladší souputníci vstoupili v šedesátých letech naplno do bratislavské politiky (včetně funkce předsedy MNV, kterou více než pět let zastával hlavní architekt města), a do velké míry tak vymazali hranici oddělující expertní milieu a politickou moc.

Zmíněné kontinuity i diskontinuity konečně nemusejí vypovídat jen o poměru sil a (jistě v lecčems specifické) konstelaci ve slovenské metropoli. Ve svých nejvýraznějších rysech mohou být a zřejmě i jsou vypouklým zrcadlem změny v povaze vládnutí v socialistickém Československu jako takovém.

In August 1964, the newly elected chairman of the Bratislava Municipal National Committee (Městský národní výbor - MNV), Ing. Milan Hladký, sent a three-page letter to the president of the Slovak National Council (Slovenská národná rada - SNR), Michal Chudík. He thanked Chudík for his congratulations on the election and outlined prospective cooperation between the city and the SNR. At first sight, a purely routine matter. Nevertheless, Hladký also included a proposal of twenty-two pages on the further development of the city, describing, among other things, the future bridging of the Danube River from Rybné Square and the necessary development of the city on the right bank of the Danube - that is, in the place where Petržalka, the largest housing estate in Czechoslovakia, was built a decade later. ${ }^{2}$ Not only these large-scale plans, but also the election of Hladký to the post of the most influential man of the second-largest and fast developing town in Czechoslovakia, can be viewed as significant.

Hladký, who was only thirty-nine years old at that time, did not have the classic career of a party apparatchik or a professional functionary climbing the ladder of party posts or bureaucratic positions. In the 1950s, he had worked as a pedagogue at the Slovak Technical University 
(Slovenská technická univerzita) and as an architect and urban planner. His star began to rise together with the demand for the fast development of Slovak towns, in particular Košice and Bratislava, in the spirit of architectural modernity. He participated in the urban planning concepts of these two towns, and in 1962, at the age of thirty-seven, he became the chief architect of Bratislava. A year later, in this capacity, he participated in the meeting of the Central Committee of the Communist Party of Slovakia (Komunistická strana Slovenska - KSS), and in 1964, became not only the chairman of the Bratislava MNV, but also a deputy of the National Assembly of the Czechoslovak Socialistic Republic (Národní shromáždění ČSSR). He remained in both posts until the late 196os, when he also became a minister in the newly established Slovak government for a short time - before having to leave all these posts in 1970 on account of his critical views on the invasion of Czechoslovakia by the Warsaw Pact armies in August 1968. During the second half of the 1960s, Hladký thus concentrated considerable political power in his hands. He could also rely on his position as a respected urban planner and architect, as well as on a vast network of contacts with other prominent figures in these fields, in Slovakia, in the Czech Lands, and also outside the borders of Czechoslovakia. While we may view the synergy of political power and expert knowledge in this concentrated form as specific, I will try to show in this study that it was a structural manifestation of the period of "technocratic socialism" rather than a coincidence. ${ }^{3}$ A fast developing and modernizing city presented a challenge which in the long-term perspective made it impossible to leave a crucial share of power in the hands of the political-bureaucratic apparatus and use urban experts merely as servants implementing political decisions dictated by ideology or force of circumstances. Nevertheless, this trend can already be observed in Bratislava (and elsewhere) several years before the urban planner and architect Hladký was elected to the highest political post in the city.

\section{Who Manages the Growth: On the Organization of the City's Development}

Bratislava entered the post-war period as a city marked by the war and the expulsion of the German-speaking population. The population fell below 150,000, ${ }^{4}$ and there were only around 30,000 flats in the city, mostly without their own sanitary facilities. ${ }^{5}$ In two decades, between 1945 and 1965 , the population increased to $262,000 .{ }^{6}$ In the subsequent years, especially on account of the construction of industrial enterprises, the influx of new residents into the city reached an annual growth of nearly 10,0oo people. In the post-war years, the housing shortage could not be remedied, and in the 1950s, despite the increasing mass construction, the problem was in fact exacerbated by the rapidly increasing influx of people into the city. ${ }^{7}$

In the national context, the mid-1950s can be seen as a first turning point in the approach to construction as well as a beginning of the emancipation of urban experts. This period saw the rejection and gradual fading of the short period of socialist realism in architecture, the return of modernism and a preference for standardized prefabricated panel construction. In Bratislava, this milestone is also reinforced by the preparation of the new Master Plan in $1954-1956$ under the baton of the key local architects of the following two decades - Milan Hladký, Dušan Kedro and Milan Beňuška.

At that time, the pressing need for effective housing construction and the resulting specific requirements for the development of the city infrastructure also started to confront the complex, unclear and in some cases even chaotic organizational structure in the area of planning and construction of the big Czechoslovak towns, including Bratislava. Although high-level decision-making powers, like all political life, were centralized (in the hands of the leadership of the Ministry of Construction, State Planning Commission (Státní plánovací komise) and since 1952 also a fifteen-member Government Committee for Construction of the Office of the Prime Minister (Vládní výbor pro výstavbu při Urradu předsednictva vlády), and all this under the supervision of the relevant Party bodies), on the level of towns, individual departments of national committees competed with the state enterprises (Agroprojekt, Hydroprojekt, Centroprojekt, etc.) in the role of investors. Semi-autonomous expert organizations such as the Research and Typification Institute (Studijní a typizační ústav) and (since 1954) the Research Institute for Construction and Architecture (Výzkumný ústav výstavby a architektury - VÚVA) also entered the design and planning process. In simple terms, we can talk about a competition of political-bureaucratic power, economic interests and expert knowledge, even though these individual levels cannot be considered identical with the individual state bodies, organizations or enterprises, as in all these areas, on all these levels and in all these structures they were rather intertwined. ${ }^{8}$ 
In the second half of the 1950s, in reaction to this unclear situation, we can observe primarily a centralization and improvement of the efficiency of construction management, which was a prerequisite for the construction of larger housing estates with hundreds to thousands of flats in the following decade. In the history of Czechoslovak architecture, the year 1956 is usually related to the end of socialist realism ${ }^{9}$ and a return to functionalism (or rather the beginning of the construction of prefabricated panel buildings).$^{10}$ However, from the perspective of the organization of construction, it was a turning point mainly because, at the behest of the Ministry of Construction (based on an analysis of a commission established to that end), an institution of general investors was established on the level of regions or big towns. As in other big towns, the existing tangle of state-owned enterprises, which could finance the construction of individual buildings as well as larger projects from their budgets, represented a problem both from the perspective of the planning of the city development and from the perspective of cost-effectiveness. In 1956, for example, there were about 200 investment projects planned in Bratislava, with 92 sectoral investors involved in them. In this respect, the leadership of the Central (Municipal) National Committee complained about the impossibility of coordinating and controlling the particular projects, as well as about the amateurism that naturally resulted from this situation (each enterprise had to use its own experts, which it either did not have or which were "needlessly scattered and underused"11). In October of the same year, as a result of national reorganization, the Town Investor for Housing and Civic Construction (Městský investor bytové a občanské výstavby $)^{12}$ could be established directly within the Bratislava national committee. From then on, under the leadership of its director, Ing. Janec, it coordinated, at least, the entire area of the construction of residential buildings and housing estates. In practice, this meant mainly the strengthening of the role of the Central National Committee as such, in particular its department for construction, which directed everything from urban planning to the economic and technical assessment of the buildings. After 1957, this influential department was led by the former rector of the University of Economic Sciences in Bratislava (Vysoká škola hospodárskych vied), Prof. Štefan Rehák. ${ }^{13}$

As in the area of investment and construction, substantial fragmentation can also be observed with regard to spatial and urban planning in the 1950s. Yet, relatively soon, external expert associations and organizations were gaining ground against the bureaucratic apparatus of the national committee. On the basis of the available resources, it seems that in the 1950s (for example in the discussion of the Master Plan [Směrný územní plán] in 1956) the key role was played by the State Design Institute for Construction of Towns and Villages (Štátny projektový ústav pre výstavbu miest a dedín) in Bratislava, mainly through its IX. Atelier. This context is also important for understanding the rise of the epistemic community of urban experts, who thought about the city in the spirit of modernist principles. ${ }^{14}$ Some years later, in the 1960 , these experts would establish the Chief Architect's Office (Útvar hlavného architekta), contribute to its emancipation and in a significant way help to formulate the policy of development of Bratislava until the early 1970s. As a matter of fact, the key figures of Atelier XI of the State Design Institute for Construction of Towns and Villages were Milan Hladký and Dušan Kedro, (not only) the future chief architects of Bratislava in the 1960 s and 1970s. But the influence of architects was also extended along different lines. Housing construction may serve as an example. At first glance, this area was centralized in the second half of the 1950s, and consequently also led to the reinforcement of the position of the Central National Committee in Bratislava, and hence of the power of bureaucracy. However, a closer look at the individual actors reveals that many posts in the bureaucratic apparatus were held by people with a background in engineering, often academics and (in earlier and later years) prominent practising architects, such as Kamil Gross.

The next chapter of this story begins on the threshold of the 1960s. At that time, it became apparent that (after less than five years) the Master Plan of the mid-1950s would require fundamental changes, more generous planning as well as more synergy between the MNV, ${ }^{15}$ construction enterprises and mainly progressive architects and urban planners, who until then often worked as individuals in different enterprises or institutions that were in competition or cooperated only on an ad hoc basis. The founding of the Chief Architect's Office of the City of Bratislava in 1962 was an important step towards creating an expert community of architects and urban planners and gradually extending expert influence. In the subsequent years, this aim was facilitated by two factors firstly, by the demand for expert knowledge in connection with the increasing complexity of urban planning and individual housing estates projects, and secondly, by the specific situation created 
when Milan Hladký, the author of the key Master Plan of 1956 and Bratislava's first chief architect, also became the chairman of the Bratislava MNV.16

The dominant position of the leadership of the Chief Architect's Office in the planning of the construction of Bratislava in the second half of the 1960s is evidenced in the way a number of key projects and agendas were being discussed - from the process of approval of the Master Plan of the City in 1967, to the discussion of the Concept Proposal of the Bratislava City Development (Návrh koncepce rozvoje města Bratislavy) up to 1980 and the organization of an international competition for the construction of Petržalka as the largest housing estate in Czechoslovakia. In the first case, Bratislava's authorities complained about insufficient coordination by the State Planning Commission (and its lower level bodies). Eventually, the coordination of the tasks under government resolution 208/1966 (i.e. the preparation of the new Master Plan of Bratislava) was entrusted directly to the deputy chief architect of the city. ${ }^{17}$ Shortly after (on 3 May 1967), this post was filled by Dušan Kedro, who until then had worked in the Slovak Commission for Technology (Slovenská komise pro techniku). ${ }^{18}$ During the time when chief architect Hladký also held the post of the chairman of the Bratislava MNV, it was the deputy chief architect who served as de facto director of the Chief Architect's Office. Even before Kedro's arrival, under the leadership of deputy chief architect Štefan Svetko, the staff of the Chief Architect's Office prepared a preliminary concept of Bratislava's development up to $198 \mathrm{o}$. This plan contains virtually all the key elements that were gradually put into practice in the 1970s - mainly the construction of the Petržalka, Dúbravka, Lamač and Karlova Ves housing estates, which also entailed major changes in the transport infrastructure of the town, including the need to invest the vast sum of CZK 300 million to build a new bridge across the Danube River. ${ }^{19}$ Moreover, in 1965 - 1968, the Chief Architect's Office prepared a general plan of the transport network and underground utilities, an urban development analysis of the city centre and a general plan of housing construction. As stated in the report on the activity of the Chief Architect's Office, commissioned by the Bratislava MNV, the office "has a decisive role in the process of urban planning, makes decisions on the investment in the space with regards to the overall concept of urban planning of the city...". Urban planning decisions issued by the office serve "on the one hand, as the basis for further preparation of projects and their realization, and on the other, in fact as determining acts for further activities in the area of investment and building regulation... ${ }^{20}$ Formally, the Chief Architect's Office was directed and controlled by the Council of the Bratislava MNV, headed by its chairman (mayor in the 1960s). As already mentioned, almost since the founding of the Chief Architect's Office until the end of the 196os, this post was held by Milan Hladký, who was also the chief architect of the city. Therefore, it was architect and mayor Hladký who, through the MNV Council, controlled the office that he led and represented from the outset.

On the threshold of normalization, in a time of renewed power ambitions of the high-level bureaucracy and party bodies, with gradually replaced cadres, the dominant position of one group (and a generational cohort) of architects started to be seen as a burden. We can thus observe the first (initially only partial) indications of a gradual curtailment of the dominant power of experts and their associations or institutions. This consisted not so much in the forced retirement of the reform communist Hladký from the post of chairman of the Bratislava MNV (other influential experts maintained their positions, as will be shown in the second part of this study), but instead in less conspicuous institutional changes. As early as 1970, the officials and the political structures to which they were subordinated began to gradually take back part of their powers, which they had lost with the establishment of the Chief Architect's Office in 1962, or more precisely, in the years that immediately followed. At the end of 1969, changes were initiated to that end at the MNV. They were aimed at extending the powers of the Office for Spatial Planning and Architecture (Utvar územního plánování a architektury), which was to direct and supervise, according to the new rules, "the activity of the Chief Architect's Office with respect to the needs of the entire society". ${ }^{21}$ Apart from assigning particular tasks, this entailed approval of projects and proposals of the Chief Architect's Office (or the possibility of intervening in them on the basis of the requirements of political bodies or other national committee departments), as well as remuneration (or non-remuneration) of the Chief Architect's Office staff. Moreover, the number of employees in the Chief Architect's Office decreased significantly, with some of them being reassigned to the Office for Spatial Planning and Architecture and becoming employees and direct subordinates of the supreme political body in the city. As became apparent in the 1970s, the emphasis on "the needs of the entire society" most often meant the need to build economically and, in view of the necessity to reduce the cost 
of housing estates per flat, flexibly change the urban planners' and architects' original plans and intentions.

The synergy between the expert institutions and individual influential urban experts, and their power over the future plans of city development, thus reached its peak in Bratislava in 1966 1970 , in other words at a time when key issues for the future (and hence also the current) shape of the city were being decided - in particular the construction of the Petržalka housing estate and the bridge across the Danube River, and the related demolition of the historical built-up area. These violent interventions in the historical character of the city were not the result of bureaucratic or political arbitrariness, but of a situation under which considerable power over the development of the city was placed in the hands of architects, urban planners and other urban experts.

\section{Knowledge and Power: Continuities of Urban Expertise}

The high demand for housing, the need of the socialist state to meet this demand and fulfil one of its key promises, as well as the centralization of the construction management described above, enabled rapid development of Bratislava in the second half of the 1960s and in the 1970s. However, these aspects alone do not explain the dominant influence of urban experts, especially urban planners and architects, and of the institutions and associations dominated by them, on the location and character of the new construction. In order to understand this important layer of Bratislava's reality mainly in the 1960s, two phenomena related to the local urban planners and architects need to be examined and clarified. These were, on the one hand, long continuities, often with roots in the pre-war period, and on the other, the dense network of contacts of this expert community. Still, it is not easy to determine which was the cause and which the effect. The position of the members of both professions had been strong in the environment of Bratislava since the birth of the First Czechoslovak Republic, but the demand for this type of expert knowledge in connection with the pressure for extensive housing construction after the mid-1950s led to its further reinforcement and qualitative transformation. For its further development, Bratislava increasingly needed competent and comprehensively thinking experts at that time. But at the same time, thanks to various surprising twists and turns of the Czechoslovak history of the previous decades, these experts were available there. Through the influence of these people on the development of the city, we can view the construction of Bratislava in the post-Stalinist era not only in the context of modern thinking about the urban environment, which had already taken root in Czechoslovakia in the inter-war period, but also in the context of the wartime social and housing policy in the Protectorate of Bohemia and Moravia and in the Slovak state.

Among those who significantly influenced the character of building Bratislava in the first two decades of state socialism, the architects Vladimír Karfík (1901 - 1996) and Emil Belluš (1899 - 1979), urban planner Emanuel Hruška (1906 - 1989) and designer and long-term Bratislava official Kamil Gross $(1899-1971)$ are the most representative of these continuities. The life paths of especially the first three architects are well known to the Slovak expert public. But with respect to the phenomena examined in this study, it is important to mention at least some of the connections that tie them together as a generational group that shaped architectural discourse and practice in Slovakia in the post-war decades.

A lifelong advocate of modernist architecture, Karfík started his career as a draughtsman for Le Corbusier, cooperated closely with F. L. Wright and established himself as a designer for Tomás and Jan A. Bata. He lived and worked in Bratislava from the end of World War II until the 1970s. Shortly after his arrival in Bratislava, he met his classmate from the Prague Technical University, Emil Belluš, an architect also inspired by functionalism, but more open to historicism in architecture. ${ }^{22}$ Belluš had already participated in debates on Bratislava's regulation plan in the 1930s, but it was in the post-war decades that Bratislava became his home and main place of work. Gočár's and Engel's pupil Hruška had the same kind of ambivalent attitude towards architectural modernism as Belluš. As an urban planner, he held important positions within the Planning Commission for the Capital City of Prague and its Environs (Plánovací komise pro hlavní město Prahu a okolí), which worked in accordance with the aims of the occupation authorities after the proclamation of the Protectorate of Bohemia and Moravia. ${ }^{23}$ Hruška, whose position in Prague was considerably damaged due to his activities during the war, also moved to Bratislava in the second half of the 1940 .

Karfík and Belluš joined forces in founding the Faculty of Architecture and Civil Engineering at the Technical University of Bratislava in 1950. At the same faculty, Hruška founded (and until 
1962 also headed) the Institute of Urban Construction. As early as the first half of the 1950s, and despite the dominance of socialist realism, Karfík and his fellow architects managed to create an institutional base at the Bratislava Technical University for educating architects in the spirit of modernism. In the mid-1950s, when Belluš became the chairman of the Union of Slovak Architects (Svaz slovenských architektů), Karfík the dean of the Faculty of Architecture ${ }^{24}$ and Hruška the dean of the Faculty of Construction at the Slovak Technical University, the atmosphere in the expert community had already changed completely. Socialist realism was stigmatized by Khrushchev as a dead end; functionalism, on the other hand, was rehabilitated, and the demand for mass housing construction throughout the entire Eastern Bloc required reinforcement of the standardization and industrialization of architecture. This put wind in the sails of other architects and designers of their generation who were linked to inter-war modernist projects. One of the most prominent of these was Kamil Gross (1899 - 1971), who had worked at the regulation department of the city administration continuously from the beginning of the 1930 until 1953. Gross was, among other things, the designer of the famous Tehelne Pole Stadium, co-author of the Danube Trade Fair (1940) exhibition-halls and of the Na Palisádach school building, as well as author of the first post-war Master Plan of Bratislava. Along with Gross, Emanuel Hruška was one of the most active contributors to this periodical in the first half of the 1960s. ${ }^{25}$

Therefore, all these architects, who had already made a significant contribution to modernist construction during the "First Republic" and World War II, in the mid-1950s, together with several other colleagues and in the conditions of the largest Slovak city, created fertile ground for the emergence of a strong epistemic community of urban experts. This community then gradually established itself in the highest political structures in Bratislava, and, in terms of the planning of the city's development, concentrated in itself not only expert knowledge, but also a considerable share of executive power.

The mentioned group of urban experts (architects, urban planners, designers and city officials controlling the planning and regulation of Bratislava), who were all born around 1900 and whose most prominent faces were Karfík, Hruška, Belluš and Gross, embodies a continuity between such seemingly different periods as inter-war Czechoslovakia, the wartime dictatorship, the post-war regime of the National Front, Stalinism and post-Stalinism. But the generation of architects born around 1925 represents an even more powerful expert group that influenced the development and shape of the city in the 1960s and 1970s. Like their colleagues, teachers and mentors who were a generation older, they were also influenced only marginally by socialist realism. However, by contrast, the career of this younger generation of modernists was linked almost from the outset to the state-socialist organization, and, in terms of the character of buildings and boroughs designed by them, to pre-fabricated panel construction.

However, most importantly, unlike their teachers and sources of inspiration, who influenced the shape of construction as academics, officials or as participants in competitions on particular buildings and projects, the architects around Milan Hladký (1925 - 2013) created a kind of independent power centre. As described in detail in the previous part of this study, its nucleus was the Chief Architect's Office in Bratislava, which was founded in 1962. Its employees also held important bureaucratic and political posts in the city, including (in the person of Hladký) the post of chairman of the MNV (or mayor as this post was temporarily called) in 1964 - 1970. As early as 1956, Dušan Kedro (1925 - 2012) worked, under Hladký's direction, on the Master Plan of Bratislava. In the late 1950 and early 1960s, he was the main designer of the new construction of the Ružinov district (carried out in 1960 - 1969). Following Hladký's appointment as chairman of MNV, Kedro worked as space planning expert in the Slovak Commission for Investment Construction (Slovenská komise pro investiční výstavbu). After 1967, he was a deputy of the chief architect, and during the first normalization decade (i.e. when the Petržalka housing estate was constructed) he was the city's chief architect. Kedro worked in the Chief Architect's Office until the early 1990s. In the first years of Hladký's sharp career ascent, the post of deputy chief architect was held by another prominent Slovak architect of the same generation, Štefan Svetko (1926 - 2009). Svetko is known as the designer of the first compact housing estate in Bratislava, known as Februárky (1962 - 1967), and as the co-author of the distinctive modernist Slovak Radio building. He also played a significant role in the preparation of the Master Plan of Bratislava of 1967, which set the framework for the development of the city in the next two decades. Among Svetko's important collaborators (not only on the mentioned Slovak Radio building) was, for example, Štefan Ďurkovič (1929 - 2009). 


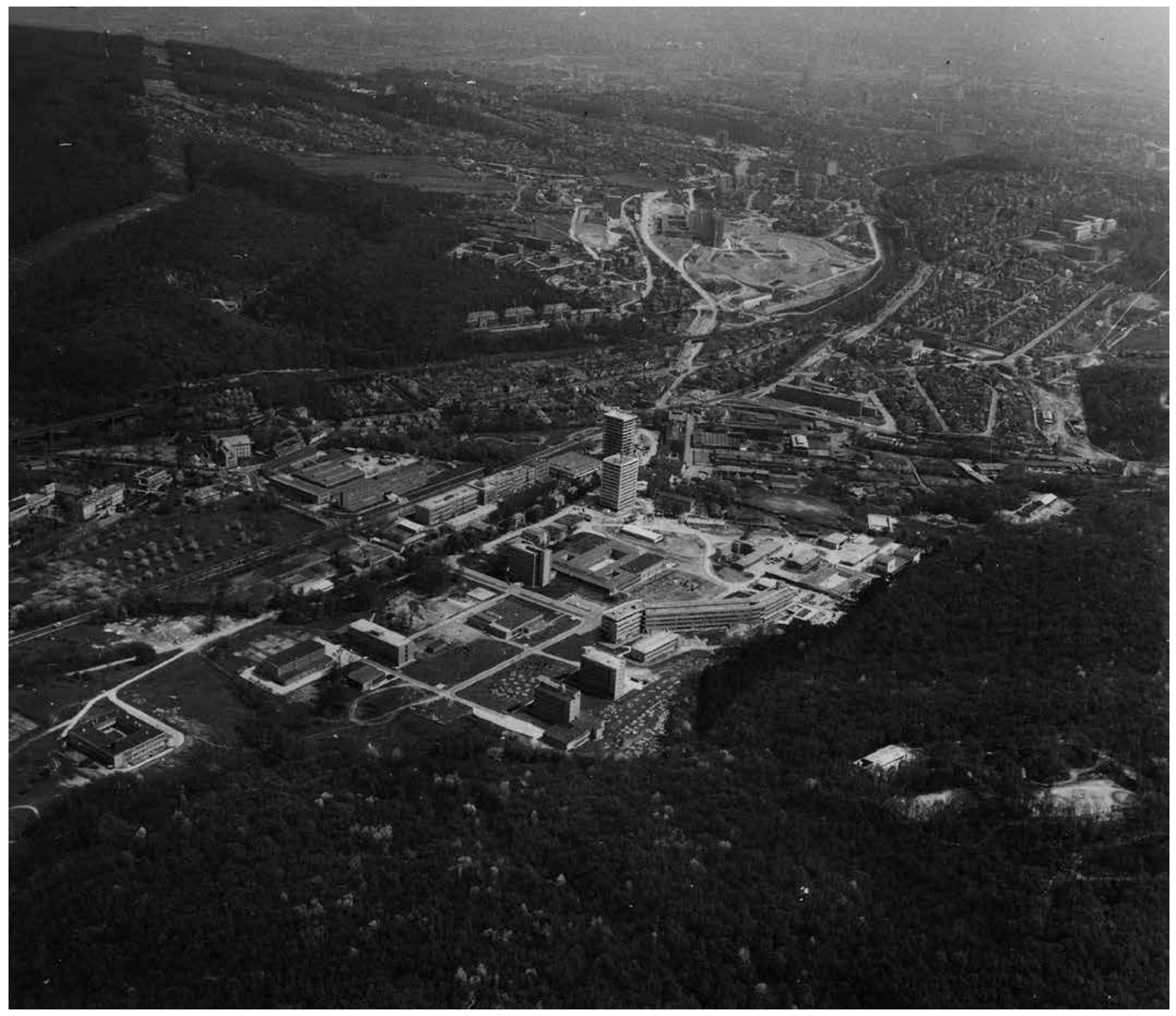

WESTERN DEVELOPMENT DISTRICT OF BRATISLAVA SCALE OF

PLANNING AND THE IDEA OF 'NONPLAN' IN EARLY POST-WAR BRITAIN SLOVAK ACADEMY OF SCIENCES (IN THE FOREGROUND) AND HOSPITAL COMPLEX KRAMÁRE (IN THE BACKGROUND)

ZÁPADNÉ ROZVOJOVÉ ÚZEMIE BRATISLAVY AREÁL SLOVENSKEJ AKADÉMIE VIED (V POPREDÍ)

A NEMOCNIČNÉHO KOMPLEXU KRAMÁRE (V POZADÍ)

Source Zdroj: Municipal Museum of Bratislava

The same generational cohort and interest group included the first graduate of architecture at the Belluš-founded Faculty of Architecture and Construction Engineering of the Slovak Technical University, Milan Beňuška (1925 - 1998), the designer of the bridgehead of the Slovak National Uprising (SNP) Bridge at Rybné Square.

All these architects, as individual creators, are well known to the Slovak architectural community, and the scope of this study does not allow to deal with their projects and buildings in Bratislava in detail; a number of them are described elsewhere. ${ }^{26}$ Predominant features of the shared discourse about the desirable character of contemporary architecture and urban development of Bratislava can be followed especially in the pages of the journal Projekt, after it had transformed from an information sheet for the staff of the State Design Institutes for the Construction of Towns and Villages into a critical periodical of the Slovak Architects' Union, mostly thanks to Kamil Gross. In the late 1950 and early 1960s, the expert discourse on the broader urban development issues of Bratislava was to a great extent determined by the urban planners and architects of the older generation, led by Hruška and Gross. ${ }^{27}$ However, this situation gradually changed. The first contributions of their pupils and followers to the debate on the broader issues of Bratislava can be seen since $1958{ }^{28}$ After the previously mentioned founding of the Chief Architect's Office and with regard to the discussion on the new Master Plan in the first half of the 1960s during Hladký's leadership 
of MNV, the dominance of this generational cohort, associated with high modernism, emphasis on transport infrastructure with the capacity to absorb large-scale individual transport, and pre-fabricated panel construction, also became evident in these conceptual issues.

The urban planning visions of these younger generation architects, under the leadership of Hladký and Kedro, were, apart from the gradually developing plan of the Petržalka housing estate, ${ }^{29}$ linked mainly to the technical solution of transport, in the form of a motorway between the historical centre and the castle complex and the bridge across the Danube River, virtually destroying Rybné Square. This met with opposition from artistic and art historical circles, or more precisely from the heritage preservation circles, but also from the generation older Emil Belluš..$^{30}$ Belluš also rejected the construction of the Petržalka housing estate in the shape of a loose belt, extending far south of the Danube River, and proposed instead its construction by the river in a concentrated form. ${ }^{31}$ However, in the second half of the 1960s, when the decisions were taken on these issues, "the academician Belluš" could no longer impose his opinion on the practising architects, who were also in power positions, such as Hladký or Kedro.

In other ways, however, we can view the planning of the Petržalka housing estate as a symbolic culmination of the activity and influence of both powerful generations of Bratislava's architects and urban planners. In particular, the international urban planning competition for the project of the Bratislava-Petržalka district, the largest future housing estate in Central Europe, illustrates not only the synergy of the entire epistemic community of the urban planning experts working in Slovakia, but also the international interconnectivity and power position of architects and urban planners in the construction of a modern European city. Milan Hladký, the MNV chairman and chief architect of the city, was naturally the animating spirit of the entire project. The committee of the international competition included his deputy at Chief Architect's Office, Štefan Svetko, and the generation older urban planner, Emanuel Hruška (at that time chairman of the urban planning section of the Union of Slovak Architects). Dušan Kedro, who, as the chief architect of the city (since 1969), later took over the entire agenda of the construction of the Petržalka housing estate, was the substitute member on the committee. As early as 1965, Hruška's (and Belluš's) contemporary Kamil Gross wrote in the pages of Projekt about the future construction in Petržalka. ${ }^{32}$ Already at that time, he vigorously rejected the criticism of bridging the Danube River from Rybné Square. ${ }^{33}$ Not even the need to demolish part of the built-up area of the existing rural and small-town Petržalka, with its population of 15,00o people, met with greater opposition. From the perspective of Kamil Gross (and probably most of the other Bratislava architects of both generations mentioned in this article), the flats in this area were "of low standard, poor layout and lacked even modestly satisfactory sanitation" and the houses were "in many cases decrepit not only in character, but also in structural and technical terms" ${ }^{34}$ Kamil Gross later became the secretary of the international competition, recording its progress in detail. ${ }^{35}$ He also commented on it in Projekt in 1968, ${ }^{36}$ and a year later in the newly established periodical Architektúra o Urbanizmus (Architecture and Urban Planning). ${ }^{37}$ Emanuel Hruška also expressed his agreement with the planned construction of Petržalka in the pages of the same journal. ${ }^{8}$

At first glance, the intervention of the Warsaw Pact armies in Czechoslovakia and the subsequent political process known as "normalization" was a heavy blow for the established and powerful expert community of Bratislava's architects and urban planners, who had filled important political and bureaucratic posts within the MNV structure in the 1960s. As a person associated with reform communism, Milan Hladký, the long-time chief architect and mayor of the city, had to gradually leave all his posts. Consequently, the entire expert network lost its direct influence over political decision-making. In the previous text, I have also pointed to the institutional changes, in particular to the weakening of the Chief Architect's Office position vis-à-vis the MNV. Moreover, the influence of older architects began to wane as they left their posts due to retirement, withdrawal from the Bratislava environment (as was the case of Emanuel Hruška ${ }^{39}$ ) or advanced age (Kamil Gross died in 1971, Emil Belluš in 1979).

Yet apart from the unquestionable discontinuities, it seems that even at the outset of normalization, definite continuities with the previous period prevailed (and influenced the reality of construction or redevelopment), whether on the levels of ideology (there was still technocratic consensus, based, among other things, on the authority of experts, of those with knowledge), institutions, or individual personalities. After all, even Bratislava's face of reform communism and critique 
of the occupation of Czechoslovakia by the Warsaw Pact armies, Milan Hladký, after being forced to leave his political posts and the post of the chief architect, continued to work in the field as head of the atelier in the Urban Planning Institute for District Planning in Bratislava [Urbanistický institut pro rajónové plánování]. His long-time collaborator and in the last few years his deputy at the Chief Architect's Office, Dušan Kedro, moved still higher up the career ladder after becoming the chief architect of the city. Kedro held this post until 1979, i.e. during the entire key period of the mass prefabricated panel construction on both banks of the Danube. Hladký's other two colleagues, the prominent architects of the reform era, Štefan Svetko and Štefan Ďurkovič, contributed significantly to the long-term plans of the urban development of the city in the 1970 s and 198 os $^{40}$ (Svetko was head of the atelier of the Bratislava branch of the State Design and Typification Institute [Štátny projektový a typizačný ústav] from 1972 and remained in this position until his retirement in 1993).

\section{Conclusion}

In his first speech as president, Václav Havel picked out an aerial view of the "metropolis of Petržalka" as being, from his perspective, a convincing illustration of the thoughtlessness of the communist leaders of Czechoslovakia and of the dismal state "we have reached". Apart from having a certain explanatory potential for the subsequent disintegration of Czechoslovakia, the criticism of the fruit of the work of several generations of prominent Slovak modernists also reveals the dominant conception of the communist governance after the Velvet Revolution. According to this view, the modern city and its problematic state was a product of arrogant rulers.

Today, after more than thirty years since 1989, at least in the expert circles this simplistic view of state socialism has lost much of its former plausibility. We are more aware of the comprehensive nature of modern governance and suspect that the state of society and the environment at the end of the 1980 os was a result of many factors. However, this does not mean that we have really abandoned long-adopted dichotomies in our thinking about the pre-November era. Thus, in relation to the issue addressed in this study, we assume on the one hand the presence of political power (represented by politicians guarding the dominant ideology) and on the other, experts serving the power through their knowledge and skills.

By analysing the building of the Slovak metropolis during the two decades from the beginning of post-Stalinism until the first years of normalization, I have offered an opportunity to revise these concepts and to understand better the role of experts and expert knowledge in the state-socialist governance. In this respect, there are at least two fascinating moments. Firstly, the continuity of the expert milieu and knowledge that can be observed through the epistemic community of urban experts in the course of the 2oth century. And then there is the extent of the influence, or even the power, that this milieu and its individual protagonists concentrated in their hands in the 196os. As it turned out, any construction of a dichotomy between politics and experts fails to reflect the historical reality here. Besides, if we talk about the power of architects in the era of culminating "organized modernity"41 in the 1960 s and early 1970s, it is not only about a retrospective analysis written by a historian. Reflections of this kind also appeared in the Slovak expert debate. For example, in 1970 Štefan Svetko wrote about the power of architect as "the power without armies" in Projekt: "Architecture gained an unprecedented dimension and social, aesthetic and technical importance and responsibility. Here you have a site of a hundred or a thousand hectares, and you build a city in which you have to create the sense of contentment or fulfilled life for thousands of your contemporaries and determine the conditions for generations. As a sick person turns to the doctor, in this case society turns to the architect, placing in his hands immense values, such as raw material, for him to multiply and transform through creative integration into social and aesthetic values." ${ }^{42}$

However, the later reflections of state socialism, especially those of the 1990s, tended to present an image of the helplessness of trained and knowledgeable experts vis-à-vis the political power. Why? Since the late 1970s, modernist projects, including those in Bratislava, faced criticism both from the experts and general public and after 1989, this criticism understandably became radicalized (and also politicized). Havel's previously mentioned presidential speech is a typical example. There were many references to the greyness of normalization, the anonymity as well as the thoughtlessness towards the living environment and historical heritage. The decay was mainly blamed on the "timelessness of normalization", during which even the high-quality plans of the 1960 s could be supposedly realized, under the political, ideological and economic pressure, only in curtailed form, if at all. Naturally, these were also the arguments of many of the original authors 
This publication was made possible with the support of the Strategy AV21 Programme.

DOC. MGR. MATĚJ SPURNÝ, PHD.

INSTITUTE OF

CONTEMPORARY HISTORY

THE CZECH ACADEMY OF

SCIENCES,

Puškinovo náměstí 9

16000 Praha 6

Czech Republic

spurny@usd.cas.cz of urban development plans, projects and buildings - that is, architects or urban planners who felt the need to defend themselves under the pressure of the changes in aesthetic perception and in the atmosphere of a society searching for a new identity through distancing itself from the failed socialist organization.

While there is no doubt that the criticism of the thoughtlessness towards the human living environment in the late normalization was justified, it did not (and still does not) take into account the fundamental change of paradigm that the thinking about cities, urban planning and architecture underwent in the 1970s and 1980s. Much (maybe most) of what the modernists considered progressive, functional and even beautiful in the 1960s, and which they were still helping to build in the early 1970s, seemed at least anachronistic even to themselves a decade later, just as it did to their younger colleagues and gradually also to a wider public. This change of perspective (figuratively speaking from Le Corbusier to Kevin Lynch) also occurred in the environment of state socialism, and with surprising speed and vehemence. ${ }^{43}$ Given this dramatic change of perspective of the human living environment, we can by no means talk about "timelessness" when it comes to the 1970 and 1980 s. Due to this fundamental change, many of the products of the then-progressive expert beliefs (and the expert community, which thanks to its power could transform these beliefs into reality) seemed in hindsight to be dead-end streets. And naturally, it was the easiest to interpret these dead-end streets as the result of the thoughtlessness or ideological blindness of the communist rulers.

As it turns out, even stories with inglorious endings offer some hope in their plot lines. It is time that we acknowledge the actors of that period - even if the post-November era could not, and even if they themselves came to doubt it in the atmosphere following the collapse of state socialism - for their genuine faith that they were building a world that would be a better place to live in. 
1 Archív hl. mesta Bratislavy (hereinafter AHMB) [Archives of the Capital City of Bratislava], F. [fund] Mestský (ústredný) národný výbor v Bratislave (hereinafter MNV) 1960 - 1968 (predsednictvo), k. [cardboard box] 2919, Zn. [location mark] 154 B (1964), Dopis Ing. Hladkého predsedovi Slovenskej národnej rady, 31 August 1964.

2 Ibid., Tézy pre rozpracovanie koncepcie rozvoja mesta Bratislavy do roku 1970 (hereinafter "Tézy").

3 For more on the definition of the concept of "technocratic socialism" see SOMMER, Vítězslav et al. 2019. Řídit socialismus jako firmu. Technokratické vládnutí v Československu 1956 - 1989Praha.

4 AHMB, F. Mestský (ústredný) národný výbor v Bratislave 1960 - 1968 (predsednictvo), k. 2919, Zn. P 1965 , Bratislava pred 20 rokmi, jej dnešok a zajtrajšok (hereinafter "Bratislava pred 20 rokmi"), 31 March 1965, p. 4.

5 MORAVČÍKOVÁ, Henrieta a kol. 2012. Bratislava: Atlas of Housing Estates 1955 - 1995 Bratislava, Slovart, p. 8.

6 Bratislava pred 20 rokmi, p. 4.

7 According to the MNV internal documents, around 32,00o flats were built in Bratislava in $1945-1965$, with an annual decrease of run-down flats of around 650. This meant a total increase of some 20,000 flats, which is a desperately small number against the background of the population increase of more than 100,00o. In 1964, that is, at the beginning of "Hladký's era", there were as many as 18, ooo unmet requests for state or cooperative flats. On this see Tézy, p. 7 and Bratislava pred 20 rokmi, p. 5.

8 On the organization of construction see also NOVOTNÝ, Michal. 2010. Bytová výstavba v padesátých letech. In: JANOVSKÝ, Igor, KLEINOVÁ, Jana and STŘíTESKÝ, Hynek. Věda a technika v Československu v letech $1945-1960$. Praha, pp. 128 - 15 o.

9 On socialist realism in the Czechoslovak architecture, see the summary provided by ZARECOR, Kimberly Elman. 2011. Manufacturing a Socialist Modernity. Housing in Czechoslovakia, 1945 - 1960. Pittsburgh.

10 For the beginnings of mass pre-fabricated panel construction in Czechoslovakia see NOVOTNÁ, Eva. 2018. Česká bytová výstavba 1958 1970. Doctoral thesis, Praha, FF UK or SKŘIVÁNKOVÁ, Lucie, ŠVÁCHA, Rostislav, KOUKALOVÁ, Martina and NOVOTNÁ, Eva (eds.). Paneláci 2, Historie sídlišt' v českých zemích 1945 - 1989. Praha: Uměleckoprůmyslové museum, (however, both these publications are limited only to the Czech context).

11 AHMB, Fond 2a/a, Zápisnice o zasadnutiach rady národného vý- boru v Bratislave (hereinafter F. 2a/a), č. (No.) 184 (1956/II), uzn. č. (Resolution No.) 95, Návrh na organizáciu systému generálneho investora (27 February 1956), pp. $515-520$.

12 AHMB, Fond 2a/a, č. 194 (1956/X/ II), uzn. č. 438, Návrh na organizačné riešenie prípravy MIBOV, pp. 331 - 333 .

13 AHMB, F. 2a/a, č. 198 (1957/II), uzn. č. 35 , Zmena vedúceho odboru výstavby, pp. $41-43$.

14 The concept "epistemic community" accents the fact that a certain group of experts (often also from different fields or countries) shares common grounds, the same value hierarchy, and social or even political goals. For more information see HAAS, Peter M. 1992. Introduction: epistemic communities and international policy coordination. In: International Organization. (46), pp. 1 - 35

15 In 1960, the existing Central National Committee in Bratislava was renamed to the Municipal National Committee.

16 For the personal links and practice of decision-making see below.

17 AHMB, F. 2a/a, č. 335 (1967/ III), uzn. č. 59, ÚHA: Informatívna správa o plnenie uzn. vlády č. 208/66, o schválenie smerného územného plánu mesta Bratislavy, pp. 15 - 34 .

18 AHMB, F. 2a/a, č. 336 (1967/IV-V), Zpráva o ustanovení námestníka ÜHA, pp. $173-174$

19 AHMB, F. 2a/a, č. 337 (1967/VI), uzn. č. 132, Predbežný návrh koncepcie rozvoje mesta Bratislavy do r. 1980, pp. $119-217$

20 AHMB, F. 2a/a, č. 348 (1968/X - XI) uzn. č. 232, Správa o činnosti Útvaru hlavného architekta mesta Bratislavy, 3 October 1968, pp. 54 - 57.

21 AHMB, F. 2a/a, č. 363 (1970/) uzn. č. 46, Návrh na doplnenie funkčnej Ütvaru územného plánovania a architektúry NVB a na pozmenenie platného štatútu Útvaru hlavného architekta mesta Bratislavy (24 February 1970, 3 annexes), pp. $63-71$.

22 For Belluš see DULLA, Matúš. 2010. Architekt Emil Belluš. Bratislava.

23 On this issue see HOŘEJŠ, Miloš. 2013. Protektorátní Praha jako německé město. Nacistický urbanismus a Plánovací komise pro hlavní město Prahu. Praha.

24 On this issue see ŠRÁMKOVÁ, Karin. 2006. Architekt Vladimír Karfík. thesis, Brno, FF MU.

25 Until the end of state socialism, Projekt played a key role in Slovakia as a space for presentation of the construction of distinctive buildings or bigger urban units, as well as a forum for critical discussion on architecture and urban planning, with contributions from foreign experts from the countries to the east as well to the west of the "Iron Curtain".

26 On this issue see Moravčíková, H. et al., 2012; DULLA, Matúš and MORAVČÍKOVÁ, Henrieta. 2003. Architektúra Slovenska v 2o. storočí. Bratislava, Slovart. MORAVČÍKOVÁ, Henrieta et al. 2013. Modern and/ or Totalitarian in the 2oth Century Architecture in Slovakia. Bratislava and others.

27 See, for example, HRUŠKA Emanuel. 1958. Tvorí sa nová sídelná štruktúra na Slovensku. Projekt. 4(5 - 6), p. 11; GROSS, Kamil. 1960. Poznámky k experimentálnej bytovej výstavbe. Projekt. 2(3-4), pp. $34-45$; HRUŠKA, Emanuel. 1960. K námetu na rozmiestnenie 40 ooo bytov v Bratislave. Projekt. 2(7), pp. $106-107$ and others.

28 See for example HLADKÝ, Milan. 1958. Spriemyselnenie výstavby a urbanizmus. Projekt. 6(5-6), pp. 3- 7; BEŇUŠKA, Milan. 196o. Príprava výstavby mestského obvodu Ružinov. Projekt. 2(3-4), pp. 46 - 49 nebo BEŇUŠKA, M. and ZÁRIŠ, Fr. 1963 Princípy územního plánu Bratislavy. Projekt. 5(4-5), pp. $77-87$.

29 This was mentioned in more detail for the first time in 1963 by M. Beňuška in relation to the Master Plan, see Beňuška, M. and Záriš, Fr., 1963, pp. $77-87$

30 Belluš already published the bases of his urban planning position in the late 1950s, see BELLUŠ, Emil. 1958. Niektoré problémy pri výstavbe mesta Bratislavy. Architektura ČSR. 17(1), pp. $41-42$. However, the dispute itself culminated only in 1970 (BELLUŠ, Emil. 1970. Základné otázky urbanistického rozvoja Bratislavy: Před novými úlohami. Architektura o urbanizmus. 4(3), pp. $3-20$ ) and continued in the following year on the pages of the same magazine, see Nová urbanistická koncepcia Petržalky z hladiska budúceho rozvoja Bratislavy (diskusia). Architektura G urbanizmus. 5(3), 1971, pp. 47 - 50. See also Dulla, M., 2010, p. 279.

31 BELLUŠ, Emil. 1970. Základné otázky urbanistického rozvoja Bratislavy: Pred novými úlohami. Architektura o urbanizmus. 4(3), pp. $3-20$; on the issue of Petržalka, pp. 8 - 10.

32 GROSS, Kamil. 1965. Úvaha k Petržalke zajtrajška. K prestavbe Petržalky. Projekt. 7(3), pp. $69-73$.

33 "Gradually, the opposition to the location of the bridge from Rybné Square, led by highly-questionable arguments on the disruption of the historical unity of the old town and castle complex, calmed down... [con- struction of the bridge] is the basic prerequisite for taking the housing construction to the right bank of the Danube River." Gross, K., 1965, p. 69.

34 GROSS, Kamil. 1968. Medzinárodná sút’až na „Ideovú urbanistickú štúdiu južného obvodu mesta Bratislavy“. Architektúra \& urbanizmus. 2(1), pp. $3-14$.

35 GROSS, Kamil. 1969. Medzinárodná sút’až Bratislava Petržalka. Bratislava.

36 GROSS, Kamil. 1967. Medzinárodná sútaž na južný obvod Bratislavy. Projekt. 9(11-12), pp. $241-255$.

37 GROSS, Kamil. 1968. Medzinárodná sút’až na „Ideovú urbanistickú štúdiu južného obvodu města Bratislavy“. Architektúra \& urbanizmus. 2(1), pp. $3-14$.

38 HRUŠKA, Emanuel. 1968. K medzinárodnej sútaži na nový mestský obvod v Bratislave Architektúra o urbanizmus. 2(1), pp. $15-34$.

39 Emanuel Hruška withdrew from discussions on the development of Bratislava at the outset of the 1970s, when, as the president of the urban planning section of the Union of Slovak Architects, he became more engaged in the issues on the level of the entire territory of Slovakia, as well as on the international level. Later, he left for Prague, where he held the post of the president of the Club for Old Prague until 1989.

40 MORAVČÍKOVÁ, Henrieta, SZALAY, Peter, HABERLANDOVÁ, Katarína, KRIŠTEKOVÁ, Laura and BOČKOVÁ, Monika. 2019.(Un)planned Bratislava. Bratislava, Veda, p. 60.

41 The term "organized modernity" is borrowed from the German sociologis Peter Wagner, who uses it to describe the phase of development of mainly European societies in the post-war decades until the "crisis of modernity" in the 1970 .

42 SVETKO, Štefan. 1970. Moc architekta. Projekt. 12(1), p. 3

43 On the rise of postmodernism as a force in the architecture of the Eastern Bloc see, for example, KULIC, Vladimir (ed.). 2019. Second World Postmodernisms: Architecture and Society under Late Socialism, Bloomsbury. For the general contex of the changes in attitudes towards the urban environment in late socialist Czechoslovakia see SPURNÝ, Matěj. 2019. Nehostinnost spočitatelného světa. In: SOMMER, Vítězslav et al. Řídit socialismus jako firmu. Praha pp. $175-190$ 


\section{$\mathbf{A} \delta \mathbf{U}$}

ARCHITEKTÚRA \& URBANIZMUS

\section{ČASOPIS PRE TEÓRIU ARCHITEKTÚRY A URBANIZMU}

JOURNAL OF ARCHITECTURAL AND TOWN-PLANNING THEORY

Ročník Volume LIV

Č́slo Number 1- 2 / 2020

REDAKČNÁ RADA EDITORIAL BOARD prof. Dr. Ing. arch. HENRIETA MORAVČíKOVÁ predsedníčka chairwoman

Fakulta architektúry STU, Bratislava

Historický ústav SAV, Bratislava

prof. Mag. phil. Dr. phil. MATTHIAS BOECKL Universität für angewandte Kunst Wien

doc. PhDr. DANA BOŘUTOVÁ, PhD.

Filozofická fakulta UK, Bratislava

prof. Ing. arch. MATÚŠ DULLA, DrSc

Fakulta architektury ČVUT, Praha

doc. Ing. arch. PAVEL HALíK, CSc

Fakulta uměni a architektury TUL, Liberec

doc. Dr. Ing. arch. SONJA IFKO

Fakulteta za arhitekturo Univerza v Ljubljani

doc. PhDr. PETR KRATOCHVÍL, CSC.

podpredseda deputy chairman

Ústav dějin umění AV ČR, Praha

prof. Ing. arch. KAREL MAIER, CSc

Fakulta architektury ČVUT, Praha

prof. Ing. arch. ÁKOS MORAVÁNSZKY, PhD.

Institut für Geschichte und

Theorie der Architektur ETH, Zürich

Dr. PÁL RITOÓK

Magyar Épitészeti Múzeum és Múemlékvédelmi

Dokumentációs Központ, Budapest

Mgr. PETER SZALAY, PhD.

hlavný redaktor managing editor

Historický ústav SAV, Bratislava

prof. Ing. arch. KARIN ŠERMAN, PhD.

Arhitektonski fakultet Sveučilište u Zagrebu

prof. Ing. arch. VLADIMÍR ŠLAPETA, DrSC.

Fakulta architektury, VUT, Brno

prof. Ing. arch. ROBERT ŠPAČEK, CSC.

Fakulta architektúry STU, Bratislava

prof. PhDr. ROSTISLAV ŠVÁCHA, PhD.

Ústav dějin umění AV ČR, Praha
M. arch. Ing.arch. MARIA TOPOLČANSKÁ, PhD.

Akademie výtvarných umění v Praze

prof. Ing. arch. PETR URLICH, CSc. Stavební fakulta ČVUT, Praha

doc. Ing. arch. PETR VORLÍK, PhD.

Fakulta architektury ČVUT, Praha

ADRESA REDAKCIE EDITORIAL ADDRESS

ARCHITEKTÚRA \& URBANIZMUS

Historický ústav SAV,

P. O. Box 198, Klemensova 19, 81499 Bratislava, SK

IČO 166944

www.architektura-urbanizmus.sk

e-mail: architektura-urbanizmus@savba.sk

REGISTROVANÉ V INDEXED AND ABSTRACTED IN Thomson Reuters Arts and Humanities Citation Index, Current Contents - Arts \& Humanities, SCOPUS, RIBA journal index, CEOL, EBSCO

VYDÁVA PUBLISHED BY

C) Historický ústav SAV, Bratislava, jún 2019

TLAČ PRINTED BY

VEDA, vydavatel'stvo SAV

Centrum spoločných činností SAV, Bratislava

ROZŠIRUJE DISTRIBUTED BY

o.z. reflektor

Šancová 17, 81105 Bratislava

Mediaprint-Kapa Pressegrosso, a.s.

Stará Vajnorská 9, 83104 Bratislava

VYCHÁDZA POLROČNE PUBLISHED SEMIANNUALLY EV 3179/09, ISSN 00448680

REDAKCIA EDITOR

Dagmar Slámová

\section{JAZYKOVÁ REDAKCIA EDITTING \\ Katarina Jostičova}

PREKLADY TRANSLATIONS

Martin Tharp (ENG), Eliška Mazalanová (SK),

Pavlina Zelničková, Martina Mojzesová (CZ),

GRAFICKÁ ÚPRAVA LAYOUT

Juraj Blaško

OBÁLKA COVER

Juraj Blaško
ROČNÉ PREDPLATNÉ

SUBSCRIBTION RATE

$18 €+$ poštovné postage $13,80 € / E U$

$25 € /$ mimo EU outside EU

Objednávky SR a ČR

subscription SR and ČR

www.ipredplatne.sk

ostatné krajiny other countries

www.architektura-urbanizmus.sk

CENA JEDNÉHO VÝTLAČKU

SINGLE ISSUE PRICE

$9 €$

Objednávky SR a ČR

subscription SR and ČR

www.ipredplatne.sk

ostatné krajiny other countries

www.architektura-urbanizmus.sk 
ARCHITEKTÚRA \& URBANIZMUS

Časopis Architektúra o urbanizmus uverejňuje štúdie z oblasti teórie architektúry a urbanizmu. Zameriava sa na súčasný stav, históriu, filozofiu a kultúru architektúry a urbanizmu, na otázky ich umeleckého charakteru a na teóriu ich technickej stránky. Zaoberá sa vzt’ahom architektúry a urbanizmu k umeniu, technike a k životnému prostrediu. Publikuje výsledky sociológie a psychológie architektúry a urbanizmu, sociálnej ekológie, výsledky výskumov z oblasti techniky prostredia a z iných disciplín, ktoré prispievajú k rozvoju teoretického ponania v architektúre a urbanizme. Zaoberá sa d’alej metódami hodnotenia kritiky architektonickej a urbanistickej tvorby a hodnotením význačných architektov, architektonických diel a období. Publikuje príspevky o výučbe architektúry a urbanizmu, recenzie odborných kníh, oko aj informácie a správy o dôležitých vedeckých podujatiach. Časopis Architektúra a urbanizmus vydáva Historický ústav Slovenskej akadémie vied v spoluprác s Ústavom dějin umění Akademie věd Českej republiky.

ARCHITEKTÚRA \& URBANIZMUS The journal Architektúra o urbanizmus provides a forum for the publication of papers on theory of architecture and town-planning. The attention is mostly concentrated on the recent state, history, philosophy and culture of architecture and town-planning, as well as on the problems of their art nature and on the theory of their technical aspects. The published papers deal with the relation of architecture and town-planning to art, technology and environment. They also present research results of architecture and town-planning sociology and psychology, social ecology, environment technology and of other theoretical disciplines which contribute to the development of the theoretical knowl edge in architecture and town-planning. The papers further deals with methods of appreciation and criticism of architectural and town-planning activities, as with appreciation of outstanding architects, architectonic works and periods. Papers on architecture and town-planning education, book reviews and information on scientific meetings are involved. The quarterly is published by the Institute of History of the Slovak Academy of Sciences in cooperation with the Art History Institute of the Academy of Sciences of Czech Republic.

\section{Obsah Content}

EDITORIAL EDITORIÁL

2 Henrieta Moravčíková, Peter Szalay (UN)PLANNED CITY

(NE)PLÁNOVANÉ MESTO

VEDECKÉ ŠTÚDIE SCIENTIFIC STUDIES

6 Lýdia Grešáková, Zuzana Tabačková, Zuzana Révészová MAPPING WITH CARE AS AN OUTLINE FOR POST-

NEOLIBERAL ARCHITECTURE METHODOLOGIES - TOOLS OF THE "NEVER-NEVER SCHOOL"

MAPOVANIE SO STAROSTLIVOSŤOU AKO PODKLAD PRE POST NEOLIBERÁLNE ARCHITEKTONICKÉ METODOLÓGIE

- NÁSTROJE „NEVER-NEVER SCHOOL"

20 Peter J. Larkham

BRITISH URBAN RECONSTRUCTION AFTER THE SECOND WORLD WAR: THE RISE OF PLANNING AND THE ISSUE OF "NON-PLANNING"

BRITSKÁ OBNOVA MIEST PO DRUHEJ SVETOVEJ VOJNE: VZOSTUP PLÁNOVANIA A OTÁZKA"NEPLÁNOVANIA"

32 Matěj Spurný

URBAN EXPERTS IN THE BUILDING

OF POST-STALINIST BRATISLAVA

URBÁNNÍ EXPERTI A BUDOVÁNÍ BRATISLAVY

$\checkmark$ ÉRE POSTSTALINISMU

44 Anna Kornélia Losonczy, Regina Balla, Hlib Antypenko, Melinda Benkő

RE-SHAPING BUDAPEST: LARGE HOUSING ESTATES AND THEIR (UN)PLANNED CENTERS

PRETVORIŤ BUDAPEŠŤ: VELKKÉ SÍDLISKÁ

AICH (NE)PLÁNOVANÉ CENTRÁ

56 Karel Maier

PLANNING OF BOHEMIAN REGIONAL CENTRES IN THE PERIOD OF THEIR INDUSTRIALISATION AND MODERNISATION: PLZEŇ AND HRADEC KRÁLOVÉ $1860-1938$

PLÁNOVÁNÍ ČESKÝCH REGIONÁLNÍCH CENTER

V OBDOBÍ INDUSTRIALIZACE A MODERNIZACE:

PLZEŇ A HRADEC KRÁLOVÉ 1860 - 1938
70 Adriana Priatková, Ján Sekan, Máté Tamáska THE URBAN PLANNING OF KOŠICE AND THE DEVELOPMENT OF A 2OTH CENTURY AVENUE MESTSKÉ PLÁNOVANIE V KOŠICIACH A VÝVOJ MESTSKEJ TRIEDY 2O. STOROČIA

89 Klára Brůhová

THE PARLIAMENT FOR PRAGUE - PROPOSALS, COMPETITIONS AND DEBATES ON ITS LOCATION AND ARCHITECTURE

PARLAMENT PRO PRAHU - NÁVRHY, SOUTĚŽE A DEBATY NAD UMÍSTĚNÍM A ARCHITEKTONICKOU FORMOU KOMPLEXU

106 Lina Degtyaryova, Oleg Olashyn

URBAN PLANNING AND CONSTRUCTION OF THE INTERWAR CITY OF UZHHOROD: MISSION INTERRUPTED

PLÁNOVANIE A VÝSTAVBA MESTA UŽHOROD

V MEDZIVOJNOVOM OBDOBII: PRERUŠENÁ MISIA

116 Peter Stec

CREATIVE TRANSFORMATIONS: THE CAMPUS PARADIGM

KREATÍVNE TRANSFORMÁCIE: PARADIGMA KAMPUSU

134 Gonçalo M. Furtado C. L.

THE LEGACY OF THE IGNASI SOLÀ-MORALES

AND THE CONTEMPORARY URBAN DEBATE

ODKAZIGNASIHO SOLA-MORALESA

A SÚČASNÁ DEBATA O MESTE

RECENZIE REWIEVS

145 Zoltán Bereczk

PATTERN RECOGNITION

ROZPOZNÁVANIE VZOROV

148 Peter Szalay

MOC EXPERTOV: KONTINUITY ČI RUPTÚRY

PRED A PO ROKU 1989

THE POWER OF EXPERTS: CONTINUITIES OR RUPTURES

BEFORE AND AFTER 1989

150 Katarína Haberlandová

SANDALOVA MIMORIADNA HĹBKA OSTROSTI

SANDALO'S EXCEPTIONAL DEPTH OF SHARPNESS 